\title{
Tahrir Defterleri Işı̆̆ında Manazan Köyünün (Kaya / Mağara Yerleşimi) XVI. Yüzyıldaki İdari, Demografik ve Ekonomik Durumu (1500-1584)
}

\author{
Emre $\mathrm{KOC}^{1}$
}

$\ddot{O} z$

Bu çalışmada Karaman ilinin $40 \mathrm{~km}$ kadar doğusunda, İbrala / Yeşildere ve Taşkale arasında yer alan ve bölgenin en önemli kaya / mağara yerleşimlerinden birisi olan Manazan'ın XVI. yüzyıldaki vaziyeti üzerinde durulmuştur. Bunu yaparken XVI. yüzyllın farklı dönemlerine ait Karaman vilayeti mufassal tahrir defterlerinden istifade edilmiştir. Bu defterlerde köy / karye olarak kaydedilmiş olan yerleşimde Müslüman ve Hristiyanların birlikte yaşadıkları anlaşılmaktadır. Ekonomik açıdan bakıldığında köyde arpa, buğday, çavdar gibi hububat üretiminin gerçekleştirildiği ve hayvancıllk yapıldığı görülmüştür. Bu ürünlerden başka, bütün tahrirlerde kovan össrünün kaydedildiği ve dolayısıyla köyde bu yüzyll boyunca bal üretimi ile iştigal edildiği belirlenmiştir. Yine 1500 tahririnde "harab" durumda olduğu belirtilen bir "asiyâb” yani değirmen kaydından, köyde önceki dönemde değirmencilik faaliyetinin de icra edildiği anlaşılmıştır. Bunlardan başka, tahrir defterlerinde Manazan köyüne bağlı olarak kaydedilmiş olan Sövüdlü, Dağkızık ve İlasun isimlerinde üç mezranın bulunduğu ve bu mezralardaki hububat üretiminin vergilendirildiği görülmüştür. Genel çerçeveden bakıldığında bu yüzyılda köy nüfus ve üretiminin artış eğiliminde olduğu söylenebilmektedir.

Anabtar Kelimeler: Manazan, Mağara, Kaya yerleşimi, Osmanll, Nüfus, Üretim

\section{Administrative, Demographic and Economic Status of Manazan Village (Rock / Cave} Settlement) in the XVIth Century (1500-1584), in The Light of the Tahrir Books

\begin{abstract}
This study was conducted with a focus on the 16th century status of Manazan, which is located between Ibrala / Yeşildere and Taşkale, $40 \mathrm{~km}$ east of Karaman province and one of the most important rock / cave settlements in the region. The "tahrir books", which were affiliated to Karaman Province and belonged to different periods of the 16th century, were utilized in the procedure. The data obtained from these documents revealed that the Muslims and Christians lived together in this settlement, which was recorded as village / karye. From the economic point of view, it was understood that cereal crops such as barley, wheat and rye were produced and animal husbandry was performed in the village. In addition to these products, hive tax was found in all the tahrirs and therefore honey was produced in the village during this century. Likewise, it was understood from an 'asiyab'(mill) which was recorded in a tahrir of year 1500 as 'harab' (ruined) that milling activity was also performed in the village in the previous era. In addition, it was indicated that three hamlets named Sövüdlü, Dağkızık and Ilasun, which were affiliated to the Manazan village, in the tahrir records and the production of the cereals in these hamlets was taxed. In general, it was seen that the population and production of the village were on the rise in this century.
\end{abstract}

Key Words: Manazan, Cave, Rock settlement, Ottoman, Population, Production

Atıf İçin / Please Cite As:

Koç, E. (2020). Tahrir defterleri 1şığında Manazan köyünün (kaya / mağara yerleşimi) XVI. yüzylldaki idari, demografik ve ekonomik durumu (1500-1584). Manas Sosyal Arasttrmalar Dergisi, 9(3), 1913-1925.

Geliş Tarihi / Received Date: 29.05.2019

Kabul Tarihi / Accepted Date: 20.02.2020

\footnotetext{
1 Arş. Gör. - Karamanoğlu Mehmetbey Üniversitesi, Edebiyat Fakültesi, Tarih Bölümü, emrekoc@kmu.edu.tr ORCID: 0000-0002-6562-2391.
} 


\section{Giriş}

Manazan, Karaman ilinin $40 \mathrm{~km}$ kadar doğusunda, İbrala vadisi içerisinde İbrala / Yeşildere ve Taşkale arasında yer alan bir kaya / mağara yerleşim alanıdır. Bir başka tanımı ile Manazan'daki bu oluşum, dünyanın insan eliyle meydana getirilmiş en büyük mağaraları arasında yer alan 5 katlı bir kaya / mağara sistemidir. Rakımı 1424 metre olan bu mağaralar, bölgenin de en fazla bilinen ve dikkat çeken kaya yerleşmeleri arasında bulunmaktadır (Tapur, 2009, s. 287; Tapur, 2017, s. 109; Kurt, 2012a, s. 99-100).

Manazan başta olmak üzere, Zanzana ve Miske gibi yerleşim alanları üzerine bir takım arkeolojik araştırmalar yapılmış, bu araştırmalar neticesinde Frig, Geç Roma, Erken Hristiyanlık, Bizans, Selçuklu ve Osmanlı dönemine dair izler tespit edilmiştir. Manazan mağaraları içinde bulunan çanak-çömlek gibi malzemeden ve diğer bazı kalıntılardan bu yerleşimin daha çok Roma ve Erken Hristiyanlık devirlerinde kullanıldığ1 anlaşılmıştır (Tapur, 2009, s. 267-273). Bunlardan başka mağara / kaya yerleşimi kısmında Ortaçağ’a ait bazı tekstil ürünlerine de rastlanmıştır (ATN, 1993, s. 17; Dawson, 2003, s. 201-210).

Doğudan ve batıdan vadiyi kontrol edebilecek stratejik bir konuma sahip olan Manazan kayalıklarının katlarına yörede, 'giriş katı', 'kum kale', 'at meydanı', ‘ölüler meydanı' gibi isimler verilmiştir (Kurt, 2011, s. 105). Giriş katının doğusunda bir İsa tasviri yer almakta ve her iki yanında yedi sıra Yunanca yazıt bulunmaktadır. Bir bölümü büyük oranda tahrip olan yazıtta okunabildiği ölçüde şunların yazılı bulunduğu tespit edilmiştir: "Ionnes şimdilik fani âlemden ayrilışla bu lahiti kemiklerinin erimesi ve vücudunun toprakla bir olması için, ellerini ve ayaklarını bağlı tutarak ve gözlerini de aralık bırakarak şöyle ki sonunu görmemek için..." (Eyice, 1971, s. 114-115; Kurt, 2012b, s. 69-70).

Mağaranın bütün bölümleri, bunların arasındaki bağlantılar, katlar arsındaki vertikal (bacamsı) çıkışlar, dağ kütlesinin insan eliyle oyulması sonucunda oluşturulmuştur. Her katın ortasında, bu kata ait geniş ve uzun bir salon bulunmaktadır. Düzenli bir şekilde işlenen bu salonun dar kenarından birisi dağın yamacına dayanmakta olup burada içeriye ışık girmesini sağlamak amacıyla açılmıs olan pencereler yer almaktadır. İlk katta oyuk biçiminde çok sayıda mezar vardır. Kumkale'de mağara duvarına ezilmiş tüf kaya ve kireç karışımından sıva vardır. Bu sıvaların dökülmesi sonucunda salon zemininde oluşan kum tabakası nedeniyle bu kata kumkale adı verilmiştir. Kumkale katından yine bir baca ile at meydanına çıkılmaktadır. Üst katlara iniş çıkışları temin etmek adına kenar kısımlara karşılıklı el ve ayak tutunma yerleri de yapılmıştır. Salonun sağında ve solunda iki katlı 60 hücre yer almaktadır. Yüzeyi sıvalı bir su sarnıcının da bulunduğu bu kata, kullanım alanının geniş olması nedeniyle at meydanı adı verilmiştir. Kattaki mezarlarda Erken Hristiyanlık ve Bizans dönemi arkeolojik buluntularına rastlanmıştır. Ölü meydanı denilen son katın duvarlarına gömülmüş 100-150 kadar ceset (doğal mumya) çıkarılmışırı. Bu katta bozulmamış bir kadın cesedi bulunmuş ve Karaman müzesinde korunma altına alınmıştır (Tapur, 2017, s. 110; Kurt, 2012a, s. 100).

Kayalıkların güney yamaçta bulunması ve kayalıklar içinde 1sı değişimin çok az olması kışın insanlara daha sıcak yazın ise daha serin bir ortamda yaşama imkânı tanımışır. Bu yerleşim 13.02.1986 tescil tarihi ile 'sit alanı' olarak kabul edilmiştir (Durum Raporu, 2012, s. 82).

Manazan ve yakın çevresinin, Hristiyanların bölgede ikamet ettikleri ilk alanlardan biri olduğu düşünülmektedir. Bu alandaki kaya yerleşimleri kayaların katlar halinde oyulması ile oluşturulmuş, buralar yaşam alanı ve kilise olarak kullanılmışır (Kurt, 2011, s. 105). İncelenen Osmanlı tahrir defterleri de köyün Hristiyan geçmişine şahitlik etmektedir. Bu kaynaklara göre XVI. yüzyılda, Larende ve sonra Kaş kazalarına bağlı bir Osmanlı "karye"si yani köyü olan Manazan'da en azından 1500’lü yılların ortalarına kadar Hristiyanların yaşamış oldukları sabittir. Bu Hristiyan reaya arasında "Vasil" gibi Hristiyan isimlere sahip olan şahıslar olduğu gibi "Aydoğmuş", "Kara" gibi Türkçe isimlere sahip olanlar da bulunmaktadır (BOA. TD. 63: 205; BOA. TD. 415: 156-157).

İbrala Deresi'nin bu alandaki yerleşime, tarımsal ve iktisadi faaliyetlere katk1 sağladığ1 düşünülebilmektedir. Nitekim XVI. yüzyıl Osmanlı kaynaklarından, bu yüzyılda Manazan köyünde arpa, buğday, burçak, çavdar bal ve bostan üretimi gerçekleştirildiği ve hayvancllık ile uğraşıldığı, ayrıca yüzyllın başında köyde harap durumda olan bir değirmenin bulunduğu anlaşılmaktadır (BOA. TD. 40: 923; BOA. TD. 63: 205; BOA. TD. 415: 156-157; TK. KKA. TD. 113: 204a-205b). 


\section{Kaynaklar}

Bu çalşmada 1500², 1518, 1539 ve 1584 tarihlerine ait olan Karaman Eyaleti mufassal tahrir defterleri kullanılmıştır.

40 Numaralı Tahrir Defteri: 1091 sayfadan oluşan 1500 tarihli ve 40 numaralı tahrir defterinin ilk sayfası eksik olmakla birlikte, defterin Konya merkez mahallelerinin tahriri ile başladığı görülmektedir. Defterin 891. ve 981. sayfaları arasında Larende kazasına dair bilgiler verilmiştir. 891. ve 903. sayfalar arasinda Larende mahalleleri, 905. ve 981. sayfalar arasında Larende köyleri yer almaktadır. Sonrasinda 982. ve 992. sayfalar arasında Madanşehr nahiyesine, 993. ve 1006. sayfalar arasında Kaş nahiyesine dair kayıtlar yer almaktadır. 1007. ve 1012. sayfalar arası ise Sarayözü nahiyesine dair bilgilerin yer aldığı sayfalardır. Defterde Manazan köyü ise 923. sayfada yer almaktadır.

63 Numaralı Tahrir Defteri: 1518 yllina ait olan 63 numaralı tahrir defteri 369 sayfadan oluşmaktadır. 3. ve 4. sayfalarda başlığı, "Fibrist-i Defter-i Mufasal-ı Vilayet-i Karaman ve Haymâna-i Vilayet-i Karaman" şeklinde kaydedilmiş olan defterin fihristi yer almaktadır. Buna göre taksimat: 1-Liva-i Mir-i Mirân (Konya), 2-Livâ-i Lârende, 3-Livâ-i Begşehri, 4-Livâ-i Akşehir, 5-Livâ-i Aksaray, 6-Livâ-i Niğde şeklindedir. Defterin 159. ve 247. sayfaları arasında Larende'ye dair kayıtlar bulunmaktadır. Defterde Manazan köyü ise 205. sayfada yer almaktadır.

415 Numaralı Tahrir Defteri: 1539 yllina ait olan 415 numaralı tahrir defteri 466 sayfadan oluşmaktadır. Defterin 143. ve 195. sayfaları arasında Manazan'ın bağlı bulunduğu Kaş nahiyesi ve köyleri hakkında bilgi verilmektedir. Defterde Manazan köyü ise 156. ve 157. sayfalarda yer almaktadır.

104 Numaralı Tahrir Defteri: Tapu Kadastro Genel Müdürlüğü Kuyud-u Kadime arşivinde yer alıp, 1584 tahririnin 1. cildi olan 104 numaralı defter 169 sayfadan oluşmaktadır. 7a ve 7b sayfalarında yer alan fihriste göre yerleşim merkezi isimleri şu şekilde verilmiştir: Livâ-i Konya, Nâhiye-i Sahrâ-i Konya, Nâhiyei Hâtunsârây, Nâhiye-i Saidili, Nâhiye-i Sudiremi, Nâhiye-i Lârende. Defterin 1b ve 5a sayfaları arasında Karaman Eyaleti Kanunnamesi vardır. Manazan köyü bu defterin 2. cildi olan 113 numaralı tahrir defterinde yer almakta olup, vergiler hususunda bu defterde yer alan kanunnameden istifade edilmiştir.

113 Numaralı Tahrir Defteri: Yine Tapu Kadastro Genel Müdürlüğü Kuyud-u Kadime arşivinde yer alan bu defter belirtildiği gibi 1584 tahririnin 2. cildini oluşturmaktadır. 170a sayfası ile başlayan defterin Kâş der Livâa-i Konya başlı̆̆ altında 171a ile 219a sayfaları arasında Kaş nahiyesi köyleri, 219b-222b sayfaları arasında da mezralar kaydedilmiştir. Defterde Manazan köyü 204a-205b sayfalarında yer almaktadır.

\section{Yüzyılda Köyün İdari Yapısı}

\section{Köy Merkezi}

Günümüzde insan yerleşiminin bulunmadı̆̆1 Manazan, 1500 tahririnde "Karye-i Manâzân tâbi-i Lârende", 1518'de "Karye-i Manâzâna an kazâa-i Lârende - Timar", 1539'da "Karye-i Mânazâân", 1584'te "Karye-i Mânazâan tâbi-i Kâş" şeklinde kaydedilmiştir. Köyün 1500 ve 1518 tahrirlerinde Larende kazasına, 1539 ve 1584 tahrirlerinde ise Kaş kazasına bağlı olduğu, 1518'deki 'tımar' ibaresinden ise köyün tımar statüsünde tasarruf edildiği anlaşılmaktadır (BOA. TD. 40: 923; BOA. TD. 63: 205; BOA. TD. 415: 156-157; TK. KKA. TD. 113: 204a-205b).

\section{Mezralar}

XVI. yüzyılda Manazan köyüne bağlı olan 3 adet mezra tespit edilebilmektedir:

Sövüdlü: 1500 tarihli tahrir defterinde "męra'a-yn Sövüdlü tâbi-i karye-i mękûre" şeklinde kaydedilmiş olan bu mezranın sadece bu tahrirde Manazan köyüne bağlı olduğu görülmektedir (BOA. TD. 40: 923).

\footnotetext{
${ }^{2} \mathrm{Bu}$ defterin genel olarak 1500 senesine ait olduğu ifade edilmekle birlikte defterin tarihi hususu tartışmalıdır. Biz de genel kanaate uyarak 1500 yllını temel almış bulunuyoruz. Ayrıca bu defterdeki kayıtlarla 1500 yllına ait olup Karaman Eyaleti evkaf tahririni ihtiva eden defterdeki kayıt benzerlikleri bu görüşü desteklemektedir. Mesela 40 numaralı tahrir defterinde İbrala köyünün öşür gelirleri İbrahim Bey İmareti'ne vakıf olarak tahsis edilmiştir. Yine 565 numaralı evkaf tahriri defterinde imarete vakıf olan yerleşim birimleri hâsılları ile birlikte kaydedilmiştir. Burada asıl önemli olan her iki defterde de imarete tahsis edilen vakıf hissesi hâsıllarının 4120 akçe olmasıdır. Yine öşrü İbrahim Bey İmareti'ne vakıf olan İvra köyünün vakıf hissesi hâsılı her iki defterde de 910 akçe olarak verilmiştir. Bunlardan başka Şeyh Hacı İsmail Zaviyesi’ne vakıf olan Evlâd-1 Hacı İsmail köyünün vakıf hissesi iki defterde de 1400 akçedir: TK. KKA. TD. 565: 60-60-65; BOA. TD. 40: 944-916-981.
} 
Dağkııık: Bu mezra 1500 tarihli tahrir defterinde, “meara'a-yı Dağkııılk tâbi-i o”, 1518 tarihli defterde

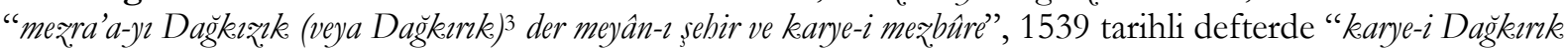

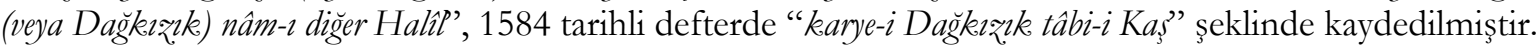

Görüldüğü üzere, 1500 tahririnde Dağkızık, Manazan köyüne bağlı bir mezradır. 1518 tahririnde yine köye bağlı olan mezranın şehir ve köy arasında yer aldığı belirtilmiştir. Mezra 1539'da ve 1584'te ise ayrı bir köy olarak kaydedilmiştir. (BOA. TD. 40: 923; BOA. TD. 63: 205; BOA. TD. 415: 157; TK. KKA. TD. 113: 196).

İlasun: 1500 tarihli tahrir defterinde "meara'a-yz İlâsûn tâbi-i karye-i mę̧kûre" ifadesiyle kaydedilen bu mezra da sadece bu tahrirde Manazan köyüne bağlıdır (BOA. TD. 40: 923).

\section{Yüzyılda Manazan'da Nüfus}

\section{Genel Olarak Köy Nüfusu}

Manazan köyü, 1500'de 25 nefer - 21 hane, 1518'de dördü Gayrimüslim (gebrân) olmak üzere 18 nefer 15 hane, 1539'da ikisi Gayrimüslim olmak üzere 37 nefer, 1584'te 132 nefer nüfusa sahiptir.

1500 yllına ait tahrir defterinde köyde bir mahlûl çiftliğin kaydedilmiş olduğu görülmektedir. Ayrıca bir de 'sipâhi-i köhne Ali Paşa' tasarrufunda olan bir nim çiftlik kaydı vardır. Bu çiftlikten 18 akçelik nim çift vergisi alınmıştır. 1584'te ise nim çift statüsünde 3 adet 'zemin' kaydı bulunmaktadır. Bunlardan birisi nâ-malûm kaydedilmekle birlikte ikisi ise "İvrâla" karyesinden şahıslara aittir.

Burada nüfus tahmininde bulunulurken hane ve nefer rakamlarının birlikte verildiği 1500 ve 1518 tahrirleri için "hane x $5+$ mücerred" formülü kullanılmıştır. Hane sayısının verilmeyip sadece nefer sayısının bulunduğu 1539 ve 1584 tahrirleri için ise "nefer x 3.45"4 formülü uygulanmış ve bu suretle aşağ1 yukarı bir nüfus tahmininde bulunulmaya çalışılmıstır.

Tablo 1. XVI. Yü̈yılda Manaz̨an Köyünün Nüfus Dağıllmı

\begin{tabular}{lcccc}
\hline Statüler & $\underline{\mathbf{1 5 0 0}}$ & $\underline{\mathbf{1 5 1 8}}$ & $\underline{\mathbf{1 5 3 9}}$ & $\underline{\mathbf{1 5 8 4}}$ \\
\hline Çift & 3 & 1 & - & - \\
\hline Nim Çift & 15 & 9 & $14(1 /$ Zemin) & 11 \\
\hline Bennâk & 3 & 3 & 11 & 62 \\
\hline Caba & - & - & 9 & 55 \\
\hline Mücerred & 4 & - & 1 (Pir-i Fani) & 1 (Pir-i Fani) \\
\hline Muaf & - & - & - & 1 \\
\hline Sagir & - & - & - & 2 \\
\hline Belirsiz & - & $\underline{18}$ & $\underline{37}$ & $\underline{132}$ \\
\hline Nefer & $\underline{25}$ & 15 & $\mathbf{1 2 7 . 6 5}$ & - \\
\hline$\underline{\text { Hane }}$ & 21 & $\mathbf{7 8}$ & $\mathbf{4 5 5 . 4}$ \\
\hline Toplam Tahmini Nüfus & $\mathbf{1 0 9}$ & & & \\
\hline
\end{tabular}

Dört tahrirde köydeki nefer statüleri göz önünde bulundurulduğunda neferlerin $\% 38$ 'ini bennak, \% 32'sini caba, \% 23'ünü nim çift, \% 3'ünü mücerred, \% 2'sini çift, \% 1'ini belirsiz \% 1'ini muaf olarak kaydedilenlerin oluşturduğu görülmektedir (BOA. TD. 40: 923; BOA. TD. 63: 205; BOA. TD. 415: 156157; TK. KKA. TD. 113: 204a-205b).

\section{Köyde Hristiyan Nüfus Varlığ1}

Belirtildiği üzere Manazan'da yaşayan nüfustan 1518'de 4 nefer, 1539'da 2 nefer Hristiyan'dır. Bu haliyle Manazan XVI. yüzyılda Gayrimüslimler ile Müslümanların birlikte yaşadıkları bir köy olma özelliğine sahiptir (BOA. TD. 63: 205; BOA. TD. 415: 156-157).

1500’de, yani yüzyllın başlarında "gebran” veya başka bir şekilde Gayrimüslim nüfusu belirten bir başlık olmasa da kayıtlı olan Bulgar, Vasil gibi isimlerin varlığından bu tarihte de Hristiyanların köyde yaşadıkları söylenebilir. Nitekim bu tahrirde Müslümanlar arasında kaydedilen Aydoğmuş veled-i Kara

${ }^{3}$ Noktalama farklılıkları dolayısıyla Dağkırık olarak da okunabilmektedir.

${ }^{4}$ Alaattin Aköz, XVI. Asırda Lârende (Karaman) Kazâsı (1992) adlı doktora tezinde hane ve nefer sayısının ayrı ayrı verilmediği defterlerde "nefer" üzerinden tahmini nüfus tespiti için 3.45 katsayısını kullanmıştır. Kendisi hane / nefer ile sadece nefer kayıtlarının birbirine en yakın sonucu hangi rakamlarla verdiğini 20 köy üzerinde tetkik etmiş ve bahsi geçen katsayıyı elde etmiştir. 
(BOA. TD. 40: 923) 1518 ve 1539 tahririnde gebran başlı̆̆ı altında kaydedilmiş olan Gayrimüslimler arasında yer almış ve her üç tahrirde de nim çift statüsünde kaydedilmiştir (BOA. TD. 63: 205; BOA. TD. 415: 156). Eğer bu üç tahrirdeki Aydoğmuş veled-i Kara'nın aynı şahıs olduğu kabul edilirse 1500 yılında da köyde Gayrimüslim bulunması ihtimali biraz daha güçlenmiş olur. Ayrıca bu şahsın adı Hristiyanlar arasında Türkçe isim kullanımı için de bir örnek teşkil etmektedir.

\section{Yılında Vergi Mükelleflerinin Adları}

Köyde kullanılan isimlere örnek teşkil etmesi açısından 1500 yllında Manazan köyünde yaşayan vergi mükellefi erkek nüfusun adları görülebildiği ölçüde aşağıda verilmiştir.

Tablo 2. 1500 Yulinda Manazan Köyünde Vergi Mükellefi Erkeklerin Adlar

\begin{tabular}{cllcll}
\hline Sıra & Ad1 & Statüsü & Sira & Adı & Statüsü \\
\hline $\mathbf{1}$ & Bulgar veled-i Sülemiş & Nim Çift & $\mathbf{1 4}$ & Haçbeg veled-i Hamza Fakı & Nim Çift \\
$\mathbf{2}$ & İsa veled-i O (Bulgar) & Mücerred & $\mathbf{1 5}$ & Göcek veled-i Okcu & Nim Çift \\
$\mathbf{3}$ & Bahşayış veled-i Seyyid Ahmed & Nim Çift & $\mathbf{1 6}$ & Vakkas veled-i Orhan & Nim Çift \\
$\mathbf{4}$ & Piri veled-i Hattab & Çift & $\mathbf{1 7}$ & Satılmş veled-i Güvendik & Nim Çift \\
$\mathbf{5}$ & İsmail veled-i Musa & Nim Çift & $\mathbf{1 8}$ & Sevindik veled-i O (Satıllmış) & Mücerred \\
$\mathbf{6}$ & Melikşeh veled-i Mesud & Çift & $\mathbf{1 9}$ & Resul veled-i Timurbaş (Demirbaş) & Bennak \\
$\mathbf{7}$ & Orucbeg veled-i Mehmed & Nim Çift & $\mathbf{2 0}$ & Bayramşeh veled-i Hasan & Nim Çift \\
$\mathbf{8}$ & Halil veled-i O (Orucbeg) & Mücerred & $\mathbf{2 1}$ & Ali veled-i İmirze & Bennak \\
$\mathbf{9}$ & Emir veled-i Hamid & Nim Çift & $\mathbf{2 2}$ & Aydoğmuş veled-i Hamza & Nim Çift \\
$\mathbf{1 0}$ & İsmail biraderi O (Emir) & Mücerred & $\mathbf{2 3}$ & Oruçbeg veled-i Varsak & Nim Çift \\
$\mathbf{1 1}$ & Pir Ahmed veled-i Hacı Yusuf & Çift & $\mathbf{2 4}$ & Reşid veled-i Mustafa Fakı & Nim Çift \\
$\mathbf{1 2}$ & Aydoğmuş veled-i Kara & Nim Çift & $\mathbf{2 5}$ & Dündar veled-i Demirci & Bennak \\
$\mathbf{1 3}$ & Vasil veled-i Göcek & Nim Çift & & & \\
\hline
\end{tabular}

Görüleceği üzere İsmail, Musa, Ahmed, Yusuf, Mehmed, Resul, Hamza, Mustafa gibi geleneksel Ortadoğu-İslam isimlerinin yanında Vasil gibi bir Hristiyan adına da rastlanmaktadır. Ayrica Bulgar, Sülemiş, Aydoğmuş, Kara, Göcek, Satılmış, Sevindik, Güvendik, Okcu, Orhan, Timurbaş gibi Türkçe kökenli isimlerin de fazlaca kullanıldığı görülmektedir (BOA. TD. 40: 923).

\section{Yüzyılda Manazan'da Ekonomik Durum}

Manazan köyünün, XVI. yüzyılda tarım ve hayvancık faaliyetlerinin gerçekleștirildiği bir yerleşim birimi olduğu görülmektedir. 1500 ve 1518 tahrirlerinden anlaşıldığına göre bu yıllarda köyde arpa, buğday (galle-hububat), bostan ve bal üretimi yapılmış, hayvancilık ile uğraşılmıştır. Ayrıca 1500'de köyde harab durumda olan bir asiyab (değirmen) bulunduğu kaydedilmiştir.

1539'da bu ürünlere burçak ve çavdar ürünleri eklenmiştir. 1584'te de 1539'daki üretim ve faaliyetler aynen geçerli olmuştur. Yani 1584 tahririnde de Manazan köyünde arpa, buğday, bal, burçak, çavdar, bostan üretilmiş ve hayvancılık ile meşgul olunmuştur.

Manazan köyünde ürün, şahıs ve bad-1 heva vergilerinden toplamda, 1500'de 2157, 1518'de 2184, 1539'da 3581, 1584'te 10.000 akçe vergi tahsil edilmiştir (BOA. TD. 40: 923; BOA. TD. 63: 205; BOA. TD. 415: 156-157; TK. KKA. TD. 113: 204a-205b).

\section{Ekonomik Faaliyetler ve Vergiler}

\section{Hububat Üretimi ve Vergileri}

Osmanlı Devleti'nde tarımsal üretimden alınan en önemli ve büyük vergi dalını öşür oluşturmaktaydı. $\mathrm{Bu}$ vergi halkın ziraatını yaptığ1 üründen, büyük oranda da hububattan alınmaktaydı. Ayrıca bal ve bostandan da verginin öşür adı altında alındığı görülmektedir. Arapça kökenli olan öşür, kelime olarak 1/10 anlamına gelmekle birlikte toprağın verimliliği, sulama şartları, ziraat yöntemlerine ve yerel örf ile adetlere göre büyük değişiklikler göstermekteydi. Öyle ki verginin tahsilinde 1/5, 1/6,1/8 gibi farklı rakamlar görülebilmekteydi (Barkan, 1964: 485-486; Ünal, 1999: 98-99). Bu verginin incelenen yüzyılda Larende'de 1/5 (ber vech-i hums) oranında alındığı bilinmektedir (Aköz, 1992, s. 162). 
1500 ve 1518 tahrirlerinde genel olarak arpa ve buğday (veya hububat) "el-galle" adiyla birlikte kaydedilmişlerdir. 1539 ve 1584 tahrirlerinde ise "gallât ve sâlârî" vb. başlıklar altında diğer ürünlerle birlikte adları ayrı ayrı yazılarak kaydedilmişlerdir. ${ }^{5}$

Manazan köyünde hububattan alınan verginin kile temelinde miktarına bakıldığında, 1500 tahririnde galleden 3.5, 1518'de 5, 1539 ve 1584'te tahririnde buğdaydan 7, arpadan 5 akçe vergi tahsil edilmiş olduğu görülmektedir. Çavdar ve burçak öşrü ise her iki defterde de kile başına 5 akçeden tahsil edilmiştir.

\section{- Arpa ve Buğday Öşrü}

Manazan'da, 1500'de 313 kile, 1518'de 250 kile arpa-buğday (galle-hububat) vergiye konu olmuştur. 1539'da köyde 100 kile buğday, 100 kile arpa, 1584 yllında ise köyde 200 kile buğday, 300 kile arpa vergiye konu olmuştur.

Buna göre 1500 yllında galleden 1095, 1518'de 2500 akçe vergi alınmıştır. 1539'da buğdaydan 700, arpadan 500 akçe, 1584'te buğdaydan 1400 akçe ve arpadan 1500 akçe vergi alınmıştır.

\section{- Çavdar Öşrü}

1539'da 80 kile (400 akçe), 1584'te 100 kile (500 akçe) olmak üzere toplamda 180 kile çavdar üretiminden 900 akçe vergi alınmıştır.

\section{- Burçak Öşrü}

Manazan'da 1539'da 15 kile (75 akçe), 1584'te 120 kile (600 yerine 520 akçe yazılmıştır) burçak üretimi vergiye konu olmuştur. Yani her iki tahrirde toplam 135 kile burçaktan 595 akçe vergi alınmıştır.

\section{- Bostan Öşrü}

Bostan, karpuz, kavun veya bunların yetiştirildiği tarla anlamındadır (Çağatay, 1947, s. 490). 104 numaralı tahrir defterinin başında "Ahval-i mirabiye der Konya" isimli başlığın altında bostan vergisi ve toplanmasına dair bazı bilgiler yer almaktadır. Buna göre bostanın iyisinin her dönümünden öşür bedeli yirmi akçe alındığının kadim defterde yazılı olduğu ifade edilmiştir. Ayrıca önceki defterlerdeki kanunnamede her evleğinden on beş akçe alındığı zikredilmiştir. $\mathrm{Kem}^{6}$ bostandan ise öşrün mahsulün kıymetine göre alındığına değinilmiştir.?

Bu vergi Manazan köyünden, 1500 tahririnde 15, 1518 tahririnde 10, 1539 tahririnde 28, 1584 tahririnde 250 akçe olarak tahsil edilmiştir.

\section{Hayvancilıktan Alınan Vergiler}

\section{- Kovan Öşrü}

Karaman Vilayeti kanunnamesinde "Kânûn-ı Resm-i Küvvâre der Vilâyet-i Karaman" adlı başlı̆ı̆n altında kovan vergisine dair bazı bilgiler yer almaktadır. Bu bilgiler "... her kovâna ikişer akça resm-i küuvâre dey $\hat{u}$ viregelïb “ösr alınmak mutadlar olduğuna...”, şeklinde kaydedilmekle buradan kovan başına iki akçe alınacağ1 anlaşılmaktadır (TK. KKA. TD. 104: Kânûn-ı Resm-i Küvvâre der Vilâyet-i Karaman).

Bu vergi Manazan köyünden, 1500 tahririnde 290, 1518 tahririnde 200, 1539 tahririnde 600, 1584 tahririnde 1000 akçe olarak tahsil edilmiştir.

\footnotetext{
5 Vergi 1518'de bazen, istisnai olarak Çomaklar, İkikilise, Foni hâsıllarında ve İbrala köyü vakıf hissesi kısmında "gendüm” (buğday) ve "şair” (arpa) şeklinde ayrı ayrı yazılabilmiştir: BOA. TD. 63: 185-166/167-180-210.

6 Kanunnamede ilkin "bostanın eyüsünden” demekle bu ürün vergisinin özellikleri belirtilmiş, sonrasın da "... ve kem bostan” ifadesiyle farklı bilgiler verilmiştir. Buradan anlaşıldığına göre "kem bostan" kelime anlamına da uygun olarak "eyü bostan"dan farklı ve zıt bir anlam ifade etmiş olmalıdır. TK. KKA. TD. 104: Abvâl-i Mîrâbiye der Konya.

7 “ ... ve dönüm dahi dört evlektir...”: TK. KKA. TD. 104: Ahvâl-i Mîrâbiye der Konya; “... ve bostânın eyüsünden her dönümünden bedel-i 'öşr yigirmi akca alındığı defter-i kadimde mestûrdur defâtir-i 'atikde kânûnnâmede her evlekden on beş akca alınur deyû kayd olunduğu sehven vâki’ olmuştur ve kem bostân mahsûl-i kıymetine göre alınur ve bostânı bozulmadan görülmek kânun-1 kadimdir şimdi tehir edeler bostân bozulduktan sonra halk1 tazyik? ederler yerlerin ölcüb eyü bostân resmi alurlar müslümânlara zulmeden mübâşirleri men eylemek lazımdır ve mirâb resmine za'îm ve 'âmil ve şâkird olanlar ekin ekmek memnûadır ve bazı dolablarki kendü suyıyla ol yeri suvâra sebzevâtından 'öşr alınmayub üzümünden ve yemişinden 'öşr alınur ve nefs-i şehr içinde olan bağçelerden ve bostânlardan ‘öşr alınmamak kânun-1 kadimdir taleb olunmaya...”: TK. KKA. TD. 104: Abvâl-i Mîrâbiye der Konya.
} 


\section{- Ganem Resmi}

Timar tasarruf edenlerden, asıl sipahi olanlardan veya kadimden kapıkulu olanlardan ve bir takım şartlara haiz olanlardan alınmayan bu vergi bir kuzusu ile sayılmakla birlikte iki koyun veya keçiye bir akçe olarak alınmıştır (TK. KKA. TD. 104: Kânûn-ı Resm-i Ağnâm ve Resm-i Asìyâb).

İki koyun ya da keçiye bir akçe alındığı bilindiğinden alınan vergiden yola çıkarak hayvan sayısı tahmini olarak belirlenebilmektedir. Ganem resmi Manazan'da 1500'de 250, 1518'de 250, 1539'da 640 ve 1584 'te 2100 akçe olarak tahsil edildiğinden tahmini koyun sayısı sırasıyla 500, 500, 1280, 4200 olarak tahmin edilebilmektedir.

\section{Şahsa Bağlı Vergiler}

\section{- Resm-i Çift}

Çift resmi Osmanlı Devleti sınırları içerisinde bir çiftlik veya bunun yarısı kadar arazi tasarruf eden, tahrir defterlerinde 'raiyyet' kaydedilmiş olan neferlerden senede bir defa alınan bir vergidir. Bu verginin miktarı bölgesel özelliklere göre az çok birbirinden farklılık göstermiştir (Çağatay, 1947, s. 496-497).

Bir çiftçi ailesine yetecek genişlikte küçük zirai işletmeler olan bu reaya çiftliklerinin bölünmemesi devletin önemle üzerinde durduğu bir mesele olmuştur. Bu çiftlikler en fazla 'nim çift' olarak ikiye bölünebilmiştir (İnalc1k, 1996, s. 38).

İncelenen alanda çift resmi 36 akçe, nim çift resmi 18 akçe olarak tahsil edilmiştir. Buna göre Manazan'da bu vergi 1500 tahririnde 396, 1518'de 216, 1539'da 252 akçe miktarınca alınmıştır.

\section{- Resm-i Bennak}

Bennak veya bazı bölgelerde eski devirlerde karşılaşılan adı ile "benlâk" evli raiyyet demektir. Defterlerde mücerred olarak kaydedilenler evlenir evlenmez bennak adı altında vergi mükellefi olarak yeni bir statüye tabi olmaktaydılar (İnalcık, 1996: s. 44).

1584 y1l tahriri kanunnamesinde "Kânûn-ı Resm-i Cift ve Bennâk ve Caba der Vilâyet-i Konya" başlı̆̆1 altında "... evlülerinden on iki akça bennâk resmi ergenlerinden caba resmi altı akça alınur..." denilmektedir (KKA. TD. 104: Kânûn-ı Resm-i Çift ve Bennâk ve Caba der Vilâyet-i Konya).

Manazan köyünde bu vergi 1500 tahririnde 36,1518'de 60,1539'da 132 akçe alınmıştır.

\section{- Resm-i Caba}

Caba ise Kayseri kanunnamesindeki tanıma göre hiç yeri ve çiftliği olmayan, bir tanıma göre ise caba mücerred (evlenmemiş bekâr) birlikte babasıyla oturup kendisine ait geliri olan mücerrede denilmekteydi (İnalcık: 1996: s. 41-42; Erdoğru, 1993, s. 474).

Bir üst başlikta da bahsedilen "... ergenlerinden caba resmi altı akşa alnur..." kanunname ibaresinden de anlaşıldığ1 gibi vergi bu statüde olan şahıslardan 6 akçe olarak tahsil edilmiştir. Buna göre Manazan köyünde, 1518 tahririnde 18,1539 tahririnde 54 akçe caba vergisi alınmıştır.

\section{- Resm-i Çift ve Bennak ve Caba}

Adı geçen bu vergiler 1584 tahririnde "resm-i çift ve bennâk ve caba" şeklinde tek bir başlık altında kaydedilmiş ve vergi Manazan köyünden 1584 tarihinde 1272 akçe olarak tahsil edilmiştir.

\section{Arızî Vergiler}

Bu vergiler zaman ve miktar olarak kesin çizgilerle belirlenmiş olmayan, verginin alınmasına sebebiyet verecek durum ve olayların meydana gelmesi neticesinde tahsil edilen vergi türleridir (Solak, 2008, 180). Bu tür vergilerin gerçekleşme ve tahsil zamanları belli olmadığından defterlere tahmini olarak kaydedilmekteydiler. $\mathrm{Bu}$ tahmini vergi miktarının belirlenmesinde ise tımar arazisinin genişliği ve nüfusu temel alınmaktaydı (Gündüz - Gülcü, 2008, s. 312).

Mufassal tahrir defterlerinde "hâsıl" başlığı altında, mahsulattan sonra bazen sadece "bâd-1 heva", bazen de "tapu ve deştbânî" ile birlikte kaydedilen bu resimler arus resmi, cürüm ve cinayet resmi, yava, abd-i abık ve kenizek gelirleri, duhan resmi ve deştbani gibi vergileri içermekteydi (Aköz, 1992: 170). 
Bütün bu vergileri ifade etmek için Osmanlı maliyesi tarafindan "bâd-1 hevâ" tabiri kullanılmaktaydı (Gündüz - Gülcü, 2008, s. 312).

\section{- Resm-i Tapu ve Deştbani}

Tımar sistemi dâhilinde reaya tarafından tasarruf edilen toprak genellikle devlete aitti. Toprağı işleyen köylüler kiracı konumundaydılar. Köylüler bu toprak üzerinde tasarruf hakkını "tapu resmi” adı verilen bir vergi ödeyerek kazanırlardı. Köylünün toprak üzerinde var olan hakları yalnızca babadan oğula geçer, köylü toprağı satamaz, hediye olarak bağışlayamaz ve izin almadan başkasına devredemezdi (İnalcık, 2009, s. 113). Karaman Vilayetine dâhil köylerde ev yeri tapusunun âlâsı 50 akçe, evsâtı 30 akçe, ednâsı 10 akçe olarak belirtilmiştir. ${ }^{8}$

Resm-i Tapu, bir nevi tazminat olan "deştbani”" ile birlikte kaydedilmiştir. Ceraim-i hayvanat olarak da bilinen bu vergi, bir reayanın tarlasına girerek ekinine zarar veren hayvanın sahibinden alınırdı (Taşkın, 2013, s. 68). Resm-i Tapu ve Deştbani Manazan'dan 1539'da 100, 1584'te 1210 akçe olarak alınmıştır.

\section{- Bad-1 Heva ve Resm-i Arus}

Zuhurata bağlı olan birçok verginin bad-1 heva olarak adlandırıldığına değinilmişti. Arus ise, "gelin" veya "gerdek resmi" olarak da bilinmekle birlikte serbest tımar sahiplerinin ve beylerbeylerinin nikâhlanan kızların veya dul kadınların babalarından aldıkları bir vergi idi (Taşkın, 2013, 68). Karaman Vilayetinde gerdek resmi, bakire kızdan (âlâ) 60 akçe, orta hallilerden (evsâtü'l-hâlden) 40 akçe, daha yoksul olanlardan (fakirü'l hâlden) ise 20 akçe olarak alınmaktaydı. ${ }^{9}$

Bu vergiler 1500 ve 1518 tahrirlerinde bad-1 heva, 1539 ve 1584 tahrirlerinde bad-1 heva ve resm-i arus olarak kaydedilmiştir. Vergiler Manazan'dan, 1500'de 75, 1518'de 180, 1539'da 100, 1584'te 248 akçe olarak tahsil edilmiştir.

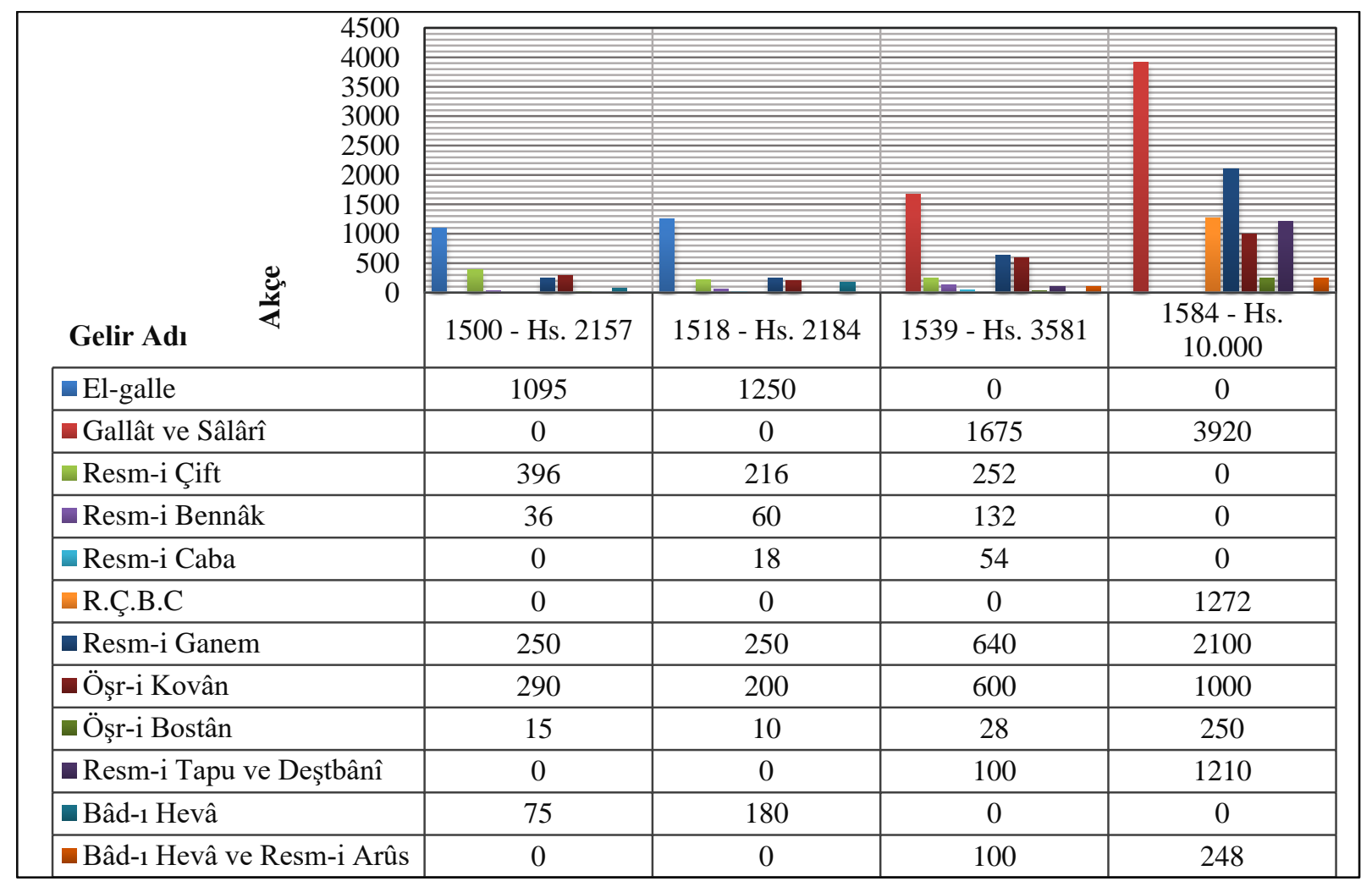

Grafik 1. XVI. Yü̈ynllda Manaz̨an Köyü Gelir Dağgllmu (Hs. = Hâsıl / R.C..B.C = Resm-i Cift ve Bennâk ve Caba)

\footnotetext{
8 "Karyelerde ev yeri tapusunun âlâsı elli akçadır evsâtı otuz akça ednâsı on akça...”: TK. KKA. TD. 104: Kânûn-ı Resmi Tapû der Kurâ-yı Vilâyet-i Karaman...

9 "Resm-i Gerdek ve 'Arûsâne âlâsı bâkire kızdan altmış akçadır evsatü’l-hâlden kırk fakîrü'l-hâlden yigirmi akçadır...": TK. KKA. TD 104: Kânûn-ı Resm-i Gerdek ve 'Arûsâne der Vilâyet-i Karaman.
} 


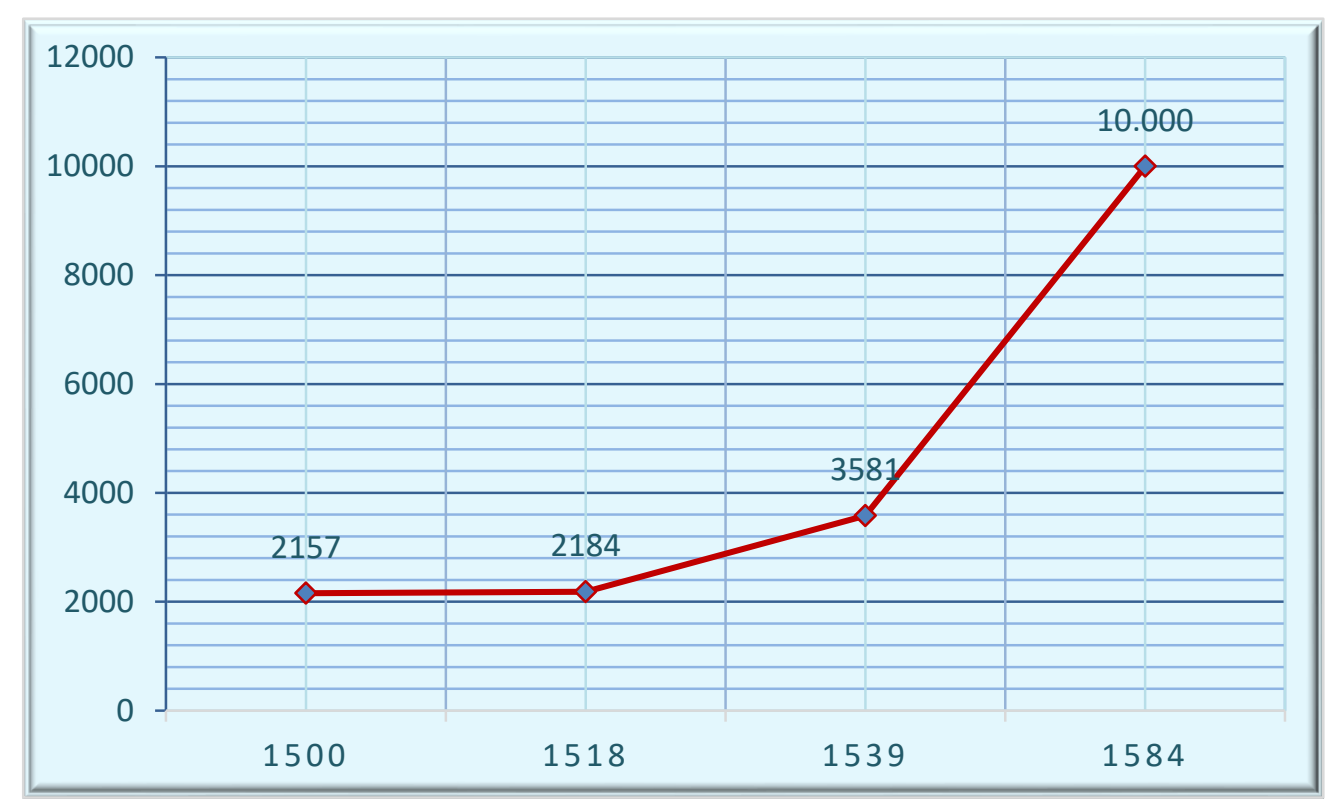

Grafik 2. XVI. Yüzyılda Manaz̧an'dan Tahsil Edilen Vergi Hâsılının Değı̆simi

\section{Mezraların Üretim ve Hâsılları}

XVI. yüzyılda Manazan'a bağlı olan mezraların sadece galle (hububat-arpa buğday) üretimi ve bundan alınan vergileri kaydedilmiştir.

Sövüdlü: Bu mezradan, 1500 tahririnde 160 kile galleden 560 akçe vergi alınmıştır.

Dağkızık: Mezrada 1500'de 12 kile galleden 42 akçe vergi alınmıştır. 1518'de ise 30 kile galleden 150 akçe vergi alınmıştır.

İlasun: Mezranın 1500 yılında, 57 kile galle üretiminden 200 akçe hâsılı bulunmaktadır. Burada vergi miktarının, 57 x $3.5=199.5$ olması gerekirken net 200 akçe vergi yazılmışıı.

\section{Sonuç}

Karaman ilinin $40 \mathrm{~km}$ kadar doğusunda bulunup son derece öneme haiz bir kaya / mağara yerleşmesi olan Manazan'ın XVI. yüzyıldaki durumuna odaklanan bu çalışmada başlıca kaynak olarak tahrir defterleri kullanılmıştır. Bu defterlerden yola çıkılarak küçük bir köy yerleşiminin ne şekilde incelenebileceğine bakıldığında, defterlerin araştırıcıya idari, demografi ve ekonomi ana başlıkları altında bir XVI. yüzyıl Osmanlı köyünün durumunu genel çerçevede ifade edebilme şansını verdiği görülmüştür. Bu sebepten çalışma belirtilen üç ana başlık etrafinda oluşturulmuştur.

Bu kaynaklardan elde edilen bilgiler 1şı̆̆ında köyün idari yapısı belli aralıklarla da olsa tespit edilebilmiştir. Bu yüzyılda bir 'karye' yani köy statüsünde bulunan Manazan'1n 1500 ve 1518 tahrirlerinde Larende kazasına, 1539 ve 1584 tahrirlerinde ise Kaş kazasına bağlı olduğu görülmüştür. Yine bu yüzyllın çeşitli dönemlerinde Sövüdlü, Dağkızık ve İlasun adlarında üç adet mezranın Manazan köyüne bağlı mezralar olduğu tespit edilmiştir. Bu mezralardan Sövüdlü sadece 1500 tahririnde, Dağkızık 1500 ve 1518 tahrirlerinde, İlasun mezrasının ise yine sadece 1500 tahririnde köye bağlı olarak kaydedildiği görülmüştür.

Demografik açıdan bakıldığında, tahmini nüfus ve bu nüfusun özelliğine dair bir takım yorumlar yapılabildiği görülmüsstür. Manazan'ın, XVI. yüzyılda Müslim ve daha az sayıda Gayrimüslimin birlikte yaşadıkları bir yerleşim olduğu anlaşılmaktadır. Köyün 1500'de 25 nefer - 21 bane, 1518'de dördü Gayrimüslim (gebrân) olmak üzere 18 nefer - 15 hane, 1539'da ikisi Gayrimüslim olmak üzere 37 nefer, 1584'te 132 nefer nüfusa sahip olduğu belirlenmiştir. Bu rakamlardan genel bir nüfus tahmininde bulunulmak istendiğinde ise köyün 1500 'de 109,1518 'de 78,1539 'da 127.65 ve 1584 'te 455.4 oranlarında tahmini nüfus rakamlarına sahip olduğu söylenebilmektedir.

Ekonomi üzerine olan bahiste ise Manazan köyünün, XVI. yüzyılda tarım ve hayvancillk faaliyetlerinin gerçekleştirildiği bir yerleşim birimi olduğu anlaşılmışır. 1500 ve 1518 tahrirlerindeki 
verilerden bu yıllarda köyde arpa, buğday (galle-hububat) ve bal üretimi yapıldığı, hayvancilık ve bostancılık ile uğraşıldığ1 anlaşılmıştır. Ayrıca 1500'de köyde harab durumda olan bir asiyab (değirmen) bulunduğu kaydedilmiş, buradan da önceki bir dönemde köyde değirmenciliğin de icra edildiği tahminine varılabilmiştir. Bunun tahmin merhalesinde kalmasının nedeni ise sonraki tahrirlerde bir asiyab kaydına rastlanılmamış olmasıdır.

1539 tahririnde bu ürünlere burçak ve çavdar ürünlerinin eklendiği, 1584'te ise 1539'daki üretim ve faaliyetlerin değişmeden devam ettirilmiş olduğu görülmüştür. Daha açı ifade edilecek olursa, 1584 tahririnde de Manazan köyünde arpa, buğday, bal, burçak, çavdar üretilmiş, hayvancllık ve bostancilık ile meşgul olunmuştur. $\mathrm{Bu}$ ekonomik faaliyetler ve devletin vergi düzeni gereğince neticede, Manazan köyünden ürün, şahıs ve bad-1 heva vergilerinden toplamda, 1500'de 2157, 1518'de 2184, 1539'da 3581, 1584 'te 10.000 akçe vergi tahsil edilmiş olduğu görülmüştür.

Manazan'a bağlı olan adı geçen üç mezrada, yani Sövüdlü, Dağkızık ve İlasun mezralarında da ufak çaplı tarımsal faaliyetin gerçekleştirildiğine değinmek gerekir. Nitekim Sövüdlü'de 1500 tahririnde, 160 kile galleden 560 akçe, Dağkızık'ta 1500'de 12 kile galleden 42, 1518'de ise 30 kile galleden 150 akçe ve İlasun'dan 1500 ylında, 57 kile galle üretiminden 200 akçe vergi alındığı görülmüştür.

\section{Etik Beyan}

"Tahrir Defterleri Işı̆ğnda Manazan Köyünün (Kaya / Mağara Yerleşimi) XVI. Yüzynldaki İdari, Demografik ve Ekonomik Dитити (1500-1584)" başlıklı çalışmanın yazım sürecinde bilimsel, etik ve alıntı kurallarına uyulmuş; toplanan veriler üzerinde herhangi bir tahrifat yapılmamış ve bu çalışma herhangi başka bir akademik yayın ortamına değerlendirme için gönderilmemiştir.

\section{Kaynakça}

\section{Arşiv Kaynakları}

BOA. TD. 40. (Başbakanlık Osmanlı Arşivi 40 Numaralı / 1500 Tarihli Karaman Vilayeti Mufassal Tahrir Defteri) BOA. TD. 63. (Başbakanlık Osmanlı Arşivi 63 Numaralı / 1518 Tarihli Karaman Vilayeti Mufassal Tahrir Defteri) BOA. TD. 415. (Başbakanlık Osmanlı Arşivi 415 Numaralı / 1539 Tarihli Karaman Vilayeti Mufassal Tahrir Defteri) TK. KKA. TD. 104. (Tapu Kadastro, Kuyud-1 Kadime Arşivi 104 Numaralı / 1584 Tarihli Karaman Vilayeti Mufassal Tahrir Defteri, Cilt 1)

TK. KKA. TD. 113. Tapu Kadastro, Kuyud-1 Kadime Arşivi 113 Numaralı / 1584 Tarihli Karaman Vilayeti Mufassal Tahrir Defteri, Cilt 2)

TK. KKA. TD. 565. (Tapu Kadastro, Kuyud-1 Kadime Arşivi 565 Numaralı / 1500 Tarihli Karaman Vilayeti Evkaf Tahriri Defteri)

\section{Diğer Kaynaklar}

Aköz, A. (1992), XVI. Asırda Lârende (Karaman) Kąâası, Selçuk Üniversitesi Sosyal Bilimler Enstitüsü, Tarih Anabilim Dalı, Basılmamıș Doktora Tezi, Konya.

ATN. (1993), (Archaelogical Textiles Newsletter), 17 November 1993.

Çağatay, N. (1947), "Osm anlı İmparatorluğunda Reayadan Alınan Resimler", Ankara Üniversitesi Dil ve Tarih Coğrafja Fakültesi Yaymlar, C. 5, ss. 483-511.

Dawson, T. (2003), "Concerning an Unrecognised Tunic From Eastern Anatolia", Byzantion, Tome LXXIII, Fascicule 1, Bruxelles.

Erdoğru, M. A. (1993), "Karaman Vilâyeti Kanunnâmeleri”, OTAM, S. 4, ss. 467-516.

Eyice, S. (1971), Karadağ ve Cevresinde Arkeolojik İncelemeler, İstanbul.

Gündüz, A., Gülcü E. (2008), "XVI. Yüzyllda Antakya Nahiyesi (1526-1584)”, Mustafa Kemal Üniversitesi Sosyal Bilimler Enstitiisü Dergisi, Cilt 6, Say1 12, ss. 289-323.

İnalc1k, H. (1996), “Osmanlilar'da Raiyyet Rüsumu”, Osmanl İmparatorluğu Toplum ve Ekonomi, İstanbul, ss. 31-65.

İnalc1k, H. (2009), Osmanh İmparatorluğgu Klasike Căg (1300-1600), İstanbul.

Karaman 2011 Yll Il Cevre Durum Raporu, Karaman Valiliği Çevre ve Şehircilik İl Müdürlüğü, 2012.

Kurt, M. (2011), Antik Çağda Karaman (Laranda) ve Yakın Cevresi, Konya.

Kurt, M. (2012b), Karaman (Laranda) Cevresindeki Kaya Yerleșimleri, Konya.

Kurt, Mehmet, (2012a), "Karaman Çevresindeki Kaya Yerleşim Sahalarına Turizm Açııından Genel Bir Bakış", IJSES, 2 (2), ss. 95-102.

Solak, İ. (2008), "XVI. Yüzyllda Zamantu Kazâsı", Maras Taribinden Bir Kesit: Dulkadirli Beylïgi Araștrmalarn IF", Editörler: Yaşar Alparslan, Mehmet Karataş, Serdar Yakar, ss. 169-181.

Tapur, T. (2009), "Atatürk'ün Ecdat Yurdu Taşkale Yerleşmesinin Coğrafyası", Selçuk Üniversitesi Türkiyat Arasttrmalar Dergisi, Say1 26, ss. 265-292. 
Tapur, T. "Karaman Çevresindeki Tarihi Yerleşim Alanları”, Türk İslam Medeniyeti Akademik. Araştırmalar Dergisi, Cilt 12, Say1 24, 2017-Yaz. ss. 101-114.

Taşkın, Ü. "Rüsûm-1 Örfiyye", Tarih Okulu, Sayı XIV, İlkbahar-Yaz, 2013, ss. 55-73.

\section{EXTENDED ABSTRACT}

This study was conducted with a focus on the 16th century status of Manazan, which is located between Ibrala / Yeşildere and Taşkale, $40 \mathrm{~km}$ east of Karaman province and one of the most important rock / cave settlements in the region. The "tahrir books", which were affiliated to Karaman Province and belonged to different periods of the 16th century, were utilized in the procedure. The data obtained from these documents revealed that the Muslims and Christians lived together in this settlement, which was recorded as village / karye.

From the economic point of view, it was understood that cereal crops such as barley, wheat and rye were produced and animal husbandry was performed in the village. In addition to these products, hive tax was found in all the tahrirs and therefore honey was produced in the village during this century. Likewise, it was understood from an 'asiyab'(mill) which was recorded in a tahrir of year 1500 as 'harab' (ruined) that milling activity was also performed in the village in the previous era.

In addition, it was indicated that three hamlets named Sövüdlü, Dağkızık and Ilasun, which were affiliated to the Manazan village, in the tahrir records and the production of the cereals in these hamlets was taxed. In general, it was seen that the population and production of the village were on the rise in this century.

The Manazan is extremely important as a rock / cave settlements in the region. In this study, focused on the situation in the XVIth century. Tahrir books were used as the main source of the study. Based on these books, it was examined how a small village could be examined. The books were given to the researcher chance to explain the situation in general in the XVIth century in terms of administrative, demographic and economic aspects of a Ottoman village. For this reason, the study was formed around three main topics.

In the light of the information obtained from these sources, the administrative structure of the village could be determined at certain intervals. Manazan was a karye (village) in this century. Manazan is attached to Larende city in 1500 and 1518 books and to Kas in 1539 and 1584 books.

It was also determined that three hamlets called Sövüdlü, Dağkızık and Ilasun were hamlets of Manazan village during various periods of this century. Among these hamlets, it was observed that the village of Sövüdlü was recorded only in 1500, in Dağkızık 1500 and 1518, and lastly, the Ilasun hamlet was recorded only in 1500 , attached to the village.

From a demographic point of view, some comments can be made about the estimated population and its characteristics. It is understood that it was a village where Muslim and lesser non-Muslims lived together in the 16th century. It was determined that the village had a population of 25 nefer (people) - 21 households in 1500, 18 nefer - 15 households, 15 of them in 1518, 37 neighbors in 1539, two of them non - Muslims, and 132 neighbors in 1584. When it is desired to make a general population estimate from these numbers, it can be said that the village has estimated population numbers of 109 in 1500, 78 in 1518, 127.65 in 1539 and 455.4 in 1584.

As mentioned, the population living in Manazan was 4 Christians in 1518 and 2 Christians in 1539. As such, Manazan is a village in which the non-Muslims and Muslims lived together in the XVIth century.

In the 1500, namely at the beginning of the century, "gebran" or other non-Muslim population is not a title indicating that the registered Bulgar, such as the presence of names such as Vasil Christians live in the village can be said on this date. As a matter of fact, Aydoğmuş veled-i Kara recorded among Muslims under this title was among the non-Muslims registered under the title of gebran in 1518 and 1539, and in all three tahrirs was recorded as "nim çift".

In the section on economy, Manazan village, it was understood that it was a settlement where agriculture and animal husbandry activities were carried out in the 16th century. According to the data from 1500 and 1518, it was understood that barley, wheat (galle-cereals) and honey were produced in the village during these years, and livestock and livestock farming was carried out. In 1500, there was an asiab (mill) in ruins in the village and it was estimated that it was performed in the village in a previous period. 


\section{KOÇ}

Tahrir Defterleri Işı̆̆ında Manazan Köyünün (Kaya / Mă̆ara Yerleşimi) XVI. Yüzyıldaki İdari, Demografik ve Ekonomik Durumu (1500-1584)

The reason for this is that it remained at the prediction stage, since no asiab record was observed in the subsequent tahrir books.

In 1539, it was seen that vetch and rye products were added to these products and in 1584 production and activities in 1539 were maintained unchanged. To put it more clearly, barley, wheat, honey, vetch, rye were produced in Manazan village in 1584, and occupation was engaged in animal husbandry and livestock. As a result of these economic activities and the tax system of the state, it was observed that a total of 2157 tax in 1557, 3584 tax in 1518, 3581 tax in 1539 and 10,000 tax in 1584 were collected from the Manazan village.

It should be mentioned that small agricultural activities were carried out in the three hamlets of Manazan, namely the Sövüdlü, Dağkizık and Ilasun hamlets. As a matter of fact, in Sövüdlü 1500, 560 akçe from 160 bushel galle, 42 bushels from 12 bushels in Dağkızık, 150 bushels from 15 bushels in 1518, and 200 bushels from 57 bushels of galle production in 1518 were collected.

\section{EKLER}

Ek 1. Manazan (2015)

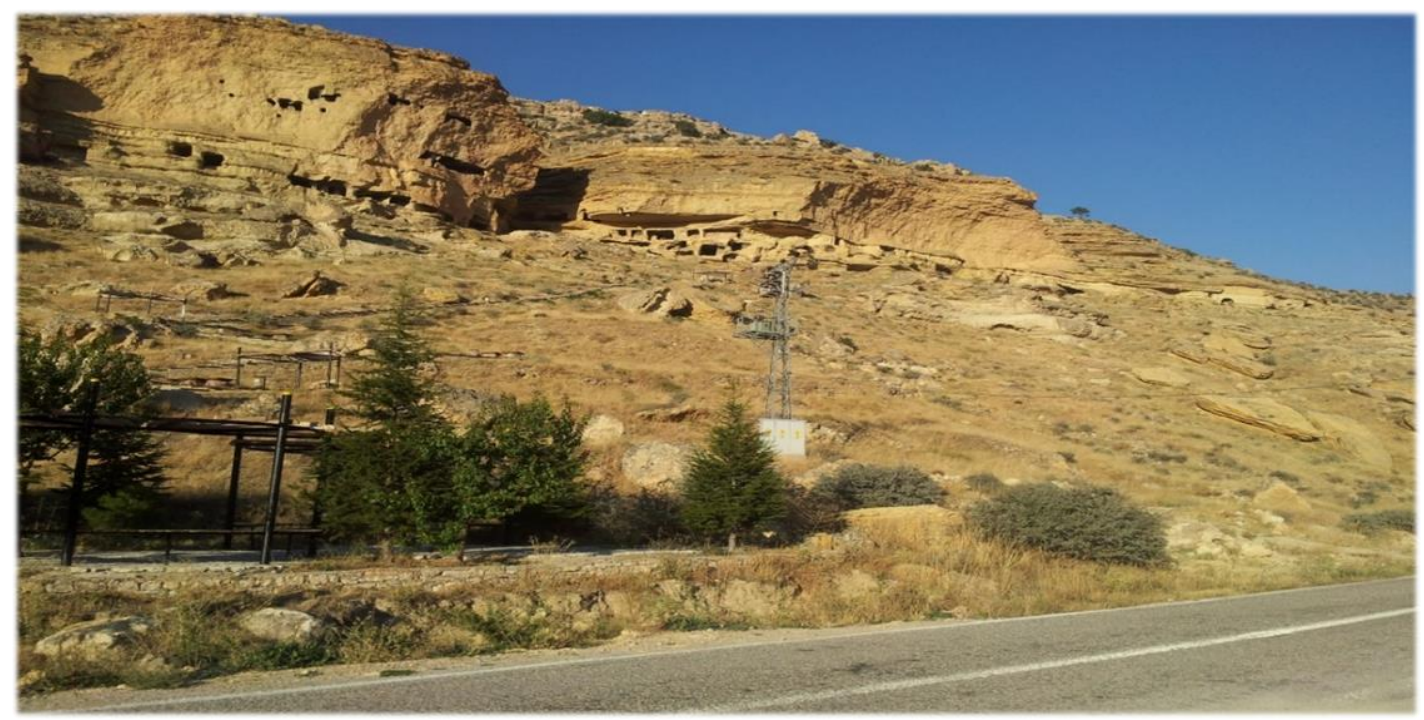

Ek 2. Manazan'ın karşı vadisi

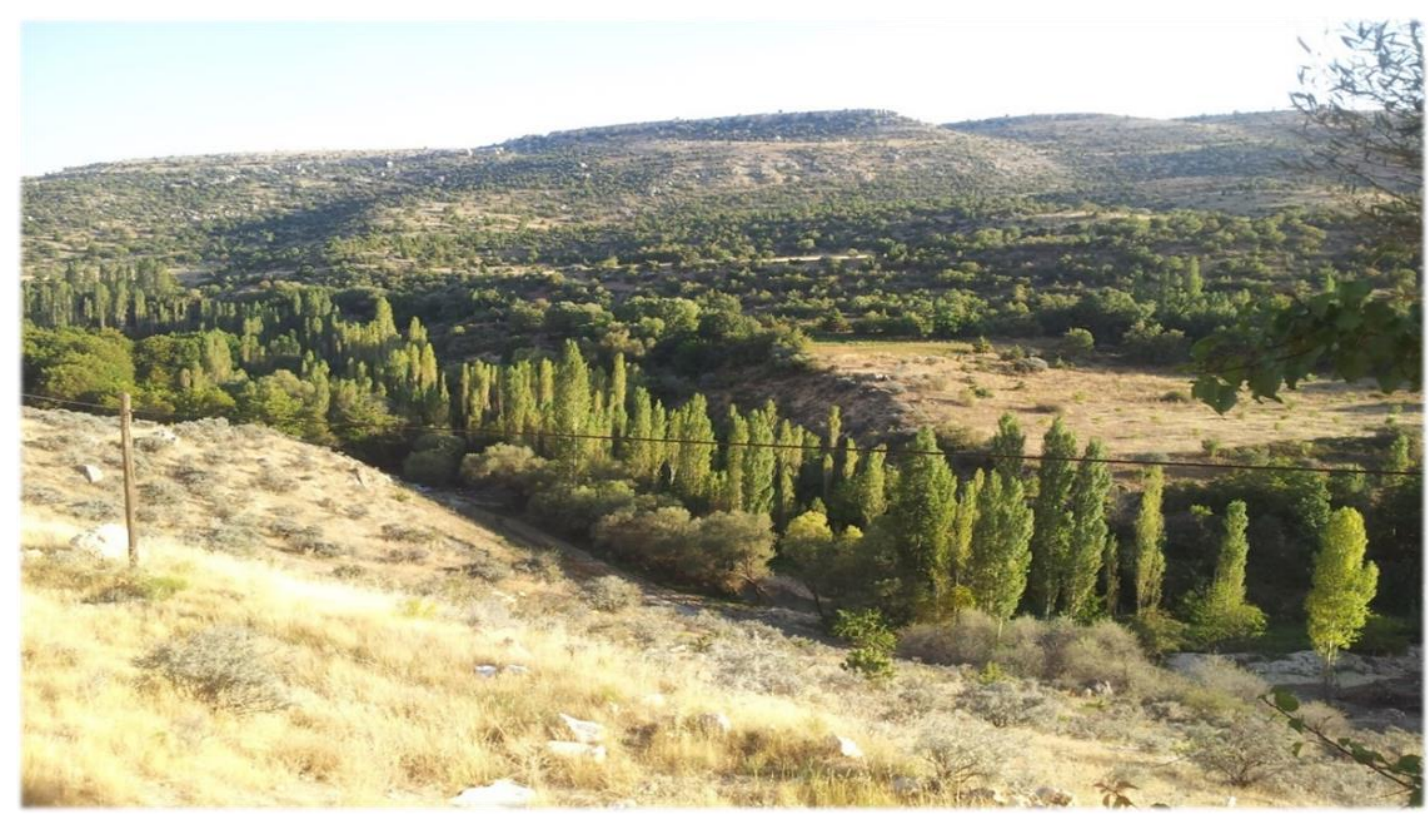


Ek 3. Diğer bir açıdan Manazan

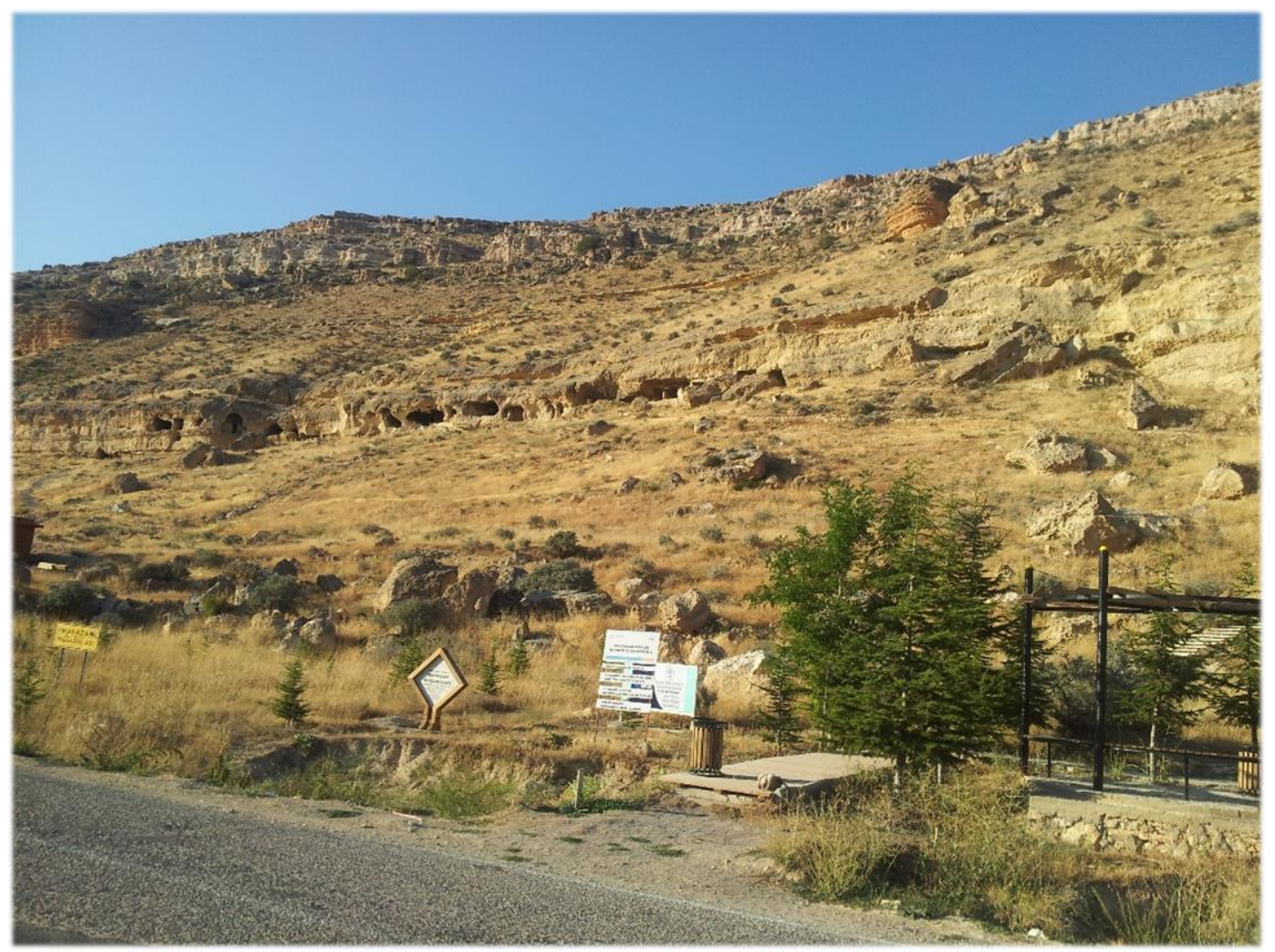

Ek 4 - Ek 5. İç kısım oyuklar (Bu fotoğraflar: Dr. Öğt. Üy. Hatice Gül KÜÇÜKBEZCI)
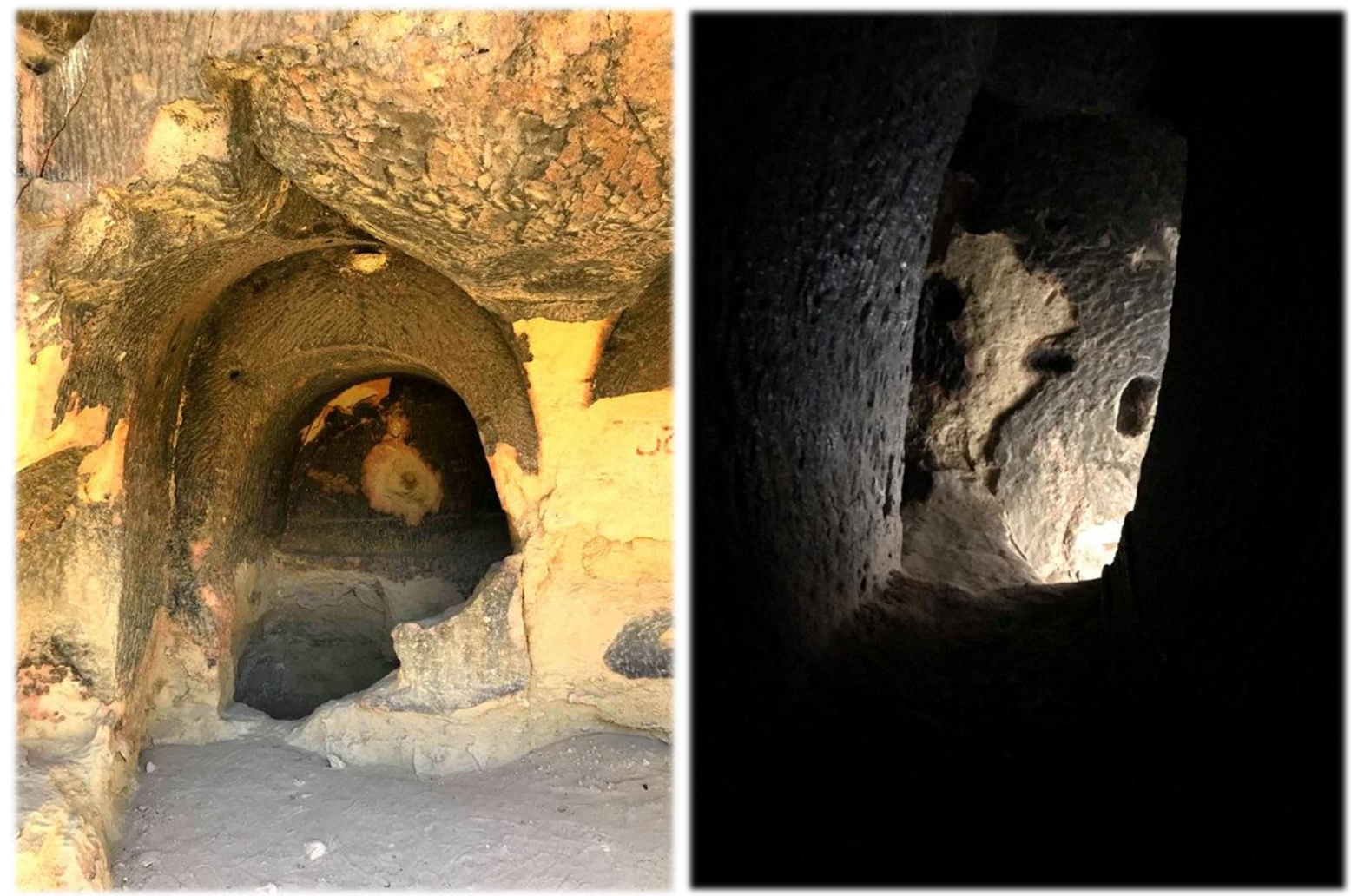